\title{
GENETIC VARIABILITY OF BRAZILIAN ALTERNARIA SPP. ISOLATES AS REVEALED BY RAPD ANALYSIS
}

\author{
Myrian Silvana Tigano $^{1 *}$; Salah Aljanabi² ${ }^{2}$ Sueli Corrêa Marques de Mello ${ }^{1}$ \\ ${ }^{1}$ Embrapa Recursos Genéticos e Biotecnologia, Brasília, DF, Brasil; ${ }^{2}$ Biology Department, MSIRI, Reduit-Mauricius.
}

Submitted: October 03, 2002; Returned to authors for corrections: January 09, 2003; Approved: February 26, 2003

\section{SHORT COMMUNICATION}

\begin{abstract}
The genetic variability of 22 isolates of the fungi Alternaria alternata and A. cassiae, obtained from Senna obtusifolia, was studied by RAPD analysis. A total of 491 scorable bands were produced with the use of 28 primers. Cluster analysis based on similarities computed from RAPD markers showed two distinct genetic groups of isolates related to both species. RAPD analysis proved to be an efficient method for detecting genetic variability of A. cassiae and A. alternata isolates occurring in S. obtusifolia, and also for distinguishing Alternaria species.
\end{abstract}

Key words: fungi, Senna obtusifolia, bioherbicide, microbial control

Several Alternaria species are responsible for diseases in cultivated plants as well in weeds. Alternaria cassiae is known as a biological control agent for sicklepod, Senna obtusifolia, a highly damaging weed $(2,7)$. In Brazil, sicklepod has been recorded as a serious problem, particularly in soybean crops. The occurrence of another fungus, Alternaria alternata, in $S$. obtusifolia was recently detected, increasing the possibilities to develop a bioherbicide to control this weed (4).

Brazilian isolates of Alternaria spp. have been characterized based on morphological and isozymes criteria. Cluster analysis obtained from the isozymes data supported the taxonomic identification of species (4).

DNA markers have become a powerful tool to study taxonomy and molecular genetic of a variety of organisms. The random amplified polymorphic DNA (RAPD) allows quick assessment of genetic variability in various taxa, and has been used to study inter and intraspecific variability among isolates of several fungal species used in biological control $(3,9,10)$.

This study was conducted to investigate polymorphism, using RAPD markers, among A. alternata and A. cassiae isolates obtained from $S$. obtusifolia (Table 1). One A. solani isolate obtained from tomato in Brasília, Brazil, was used as an outgroup. Conidia were produced in monoconidial cultures grown on potato dextrose agar (Difco) plates at $28^{\circ} \mathrm{C}$, on the dark, for 10 days. For mycelium production, conidia were inoculated into a semi-synthetic liquid medium ( $10 \mathrm{~g}$ sucrose, $2 \mathrm{~g}$ yeast extract, 1 $\mathrm{g} \mathrm{KH}_{2} \mathrm{PO}_{4}, 0.1 \mathrm{mg} \mathrm{MgSO} \mathrm{M}_{4} .7 \mathrm{H}_{2} \mathrm{O}, 0.44 \mathrm{mg} \mathrm{ZnSO} 4.7 \mathrm{H}_{2} \mathrm{O}, 0.48 \mathrm{mg}$ $\mathrm{FeCl}_{3} \cdot 6 \mathrm{H}_{2} \mathrm{O}, 0.36 \mathrm{mg} \mathrm{MnCl} 2 \cdot \mathrm{H}_{2} \mathrm{O}$ in 1 liter of distilled water). Liquid cultures were shaken at $250 \mathrm{rpm}$ at $28^{\circ} \mathrm{C}$, for 7 days. Mycelia were separated from the supernatant by filtration through filter paper (Whatman $\mathrm{N}^{\circ} 1$ ) and stored at $-80^{\circ} \mathrm{C}$.

Genomic DNA was obtained from mycelium using a universal rapid salt extraction method (1). PCR reactions were performed in 30- $\mu \mathrm{l}$ volume, with $15 \mathrm{ng}$ of each template, using the PTC-100 programmable thermal controller (MJ Research), and a temperature profile described by Tigano-Milani et al. (9). Amplifications were done using the following reaction mix: $1 \mu \mathrm{M}$ of 10 -mer primer (Operon Technologies), $200 \mu \mathrm{M}$ of each dNTP (Pharmacia Biotec), 2 units of Taq DNA Polymerase (Cenbiotec) and 1x of the polymerase's recommended buffer. Twenty-eight primers were selected for this study: OPB- 03, OPB-04, OPB-05, OPB-06, OPB-07, OPB-08, OPB-10, OPB-11,

* Corresponding author. Mailing address: Embrapa Recursos Genéticos e Biotecnologia, Caixa Postal 02372. 70849-970, Brasília, DF, Brasil. Fax: (+5561) 448- 4673. E-mail: myrian@ cenargen.embrapa.br 
OPB-12, OPB-13, OPB-15, OPB-17, OPB-18, OPB-20, OPC-02, OPC-04, OPC-05, OPC-06, OPC-07, OPC-08, OPC-10, OPC-11, OPC-12, OPC-13, OPC-14, OPC-15, OPC-16 and OPC-19. Amplified products were separated by electrophoresis in $2 \%$ agarose gel prepared in 0.5x Tris-borate-EDTA (TBE) buffer, and visualized by staining with ethidium bromide (6) and photographed under UV light.

DNA fingerprints were scored directly from the photographs. Only well resolved products were scored. The presence or absence of each fragment was considered as an independent character. RAPD markers were analyzed using NTSYS-pc V1.8 (5). A similarity matrix was calculated using Jaccard similarity coefficient. Clustering was done using the unweighted mean pair group arithmetic mean method (UPGMA) (8).

Gel electrophoresis of the different sets of RAPD reactions produced 491 scorable bands. On average, 18 bands were produced by the different 28 primers used.

Cluster analysis based on similarities computed from RAPD markers showed two distinct phenetic groups of isolates related to the species A. alternata and A. cassiae (Fig. 1). These species and the outgroup, $A$. solani, were well separated in this analysis, supporting the taxonomic identification. The group of A. cassiae isolates clustered first with the $A$. solani isolate, with approximately $25 \%$ similarity, and these two species clustered with the A. alternata group with $13 \%$ similarity. This analysis also allowed detecting intraspecific variability of Alternata spp. isolates obtained from S. obtusifolia. In the group of A. cassiae, Brazilian isolates clustered at high similarity ( $>82 \%)$, and it was not observed subgroups related to their geographic origin. Therefore, genetic variability of isolates infecting S. obtusifolia

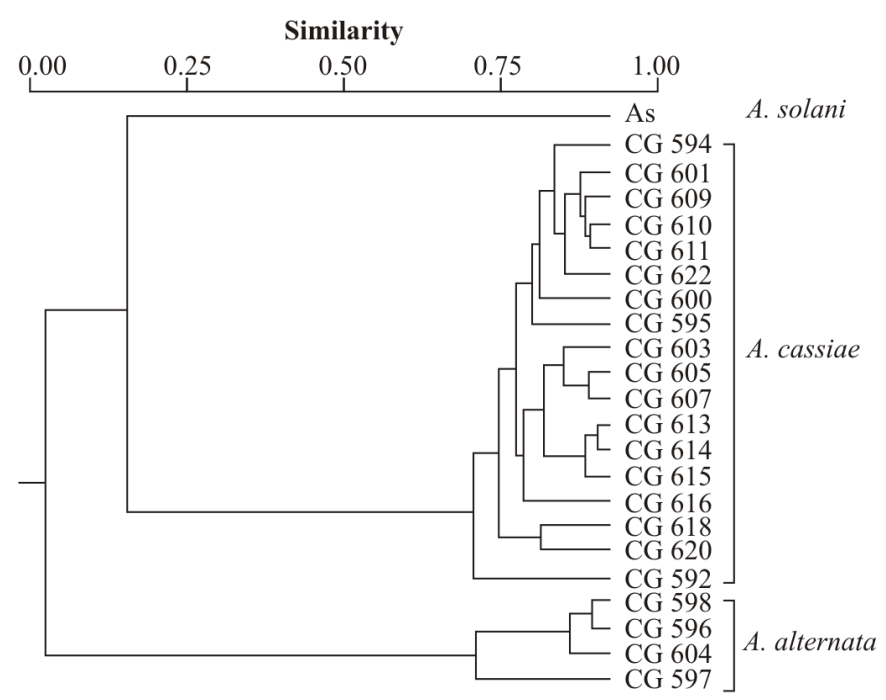

Figure 1. Relationship among Alternaria spp. strains as indicated by dendrogram constructed from RAPD analysis data. on the same geographical region was detected. The Brazilian isolates showed also high similarity ( $>79 \%$ ) with a isolate from Florida, USA (CG 592). The group of A. alternata, including four Brazilian isolates, also showed a high similarity (>79\%). In spite being obtained from only one region, the isolates presented genetic variability. This was true even for those isolates collected in the same year (Fig. 1, Table 1). Similar results have been obtained with the analysis of isozymes, using smaller number of isolates (4)

RAPD analysis proved to be an efficient method for detecting genetic variability of $A$. cassiae and A. alternata isolates occurring in S. obtusifolia, and also for distinguishing Alternaria species. However, additional work is needed on Alternaria spp. populations pathogenic to $S$. obtusifolia, which includes evaluation of larger sample sizes and isolates from diverse locations.

Table 1. Source of Alternaria spp. isolates obtained from Senna obtusifolia.

\begin{tabular}{ccc}
\hline \multicolumn{1}{c}{ Species/isolate $^{\text {a }}$} & $\begin{array}{c}\text { Geographical } \\
\text { location }^{\text {b }}\end{array}$ & Year \\
\hline A. alternata & & \\
CG598 & DF/Brazil & 1992 \\
CG604 & DF/Brazil & 1993 \\
CG596 & DF/Brazil & 1993 \\
CG597 & DF/Brazil & 1993 \\
A. cassiae & & \\
CG594 & DF/Brazil & 1990 \\
CG595 & DF/Brazil & 1991 \\
CG600 & DF/Brazil & 1992 \\
CG601 & DF/Brazil & 1992 \\
CG603 & DF/Brazil & 1993 \\
CG605 & DF/Brazil & 1993 \\
CG607 & DF/Brazil & 1993 \\
CG609 & DF/Brazil & 1993 \\
CG610 & DF/Brazil & 1993 \\
CG611 & DF/Brazil & 1994 \\
CG613 & DF/Brazil & 1994 \\
CG614 & DF/Brazil & 1994 \\
CG615 & DF/Brazil & 1994 \\
CG616 & SP/Brazil & 1995 \\
CG618 & AL/Brazil & 1995 \\
CG620 & AL/Brazil & 1995 \\
CG622 & AL/Brazil & 1995 \\
CG592 & FL/USA & $-{ }^{c}$ \\
\hline
\end{tabular}

${ }^{a}$ Code at Embrapa Genetic Resources and Biotechnology Collection, Brasília, DF, Brazil; ${ }^{b}$ Letter abbreviations refer to Brazilian states: AL, Alagoas; DF, Federal District; SP, São Paulo; ${ }^{\mathrm{c}}$ Unknown. 


\section{ACKNOWLEDGMENTS}

We thank Bonifácio P. Magalhães, Embrapa Recursos Genéticos e Biotecnologia, for reviewing the manuscript. This work was supported in part by the Conselho Nacional de Desenvolvimento Científico e Tecnológico (CNPq).

\section{RESUMO}

\section{Variabilidade genética de isolados de Alternaria spp, revelada através da análise de RAPD}

A variabilidade genética entre 22 isolados dos fungos Alternaria alternata e A. Cassiae, obtidos de Senna obtusifolia, foi estudada através da análise de RAPD. No total, 491 bandas foram selecionadas com o uso de 28 primers. $\mathrm{O}$ agrupamento baseado em similaridades computadas dos marcadores mostrou dois distintos grupos de isolados relacionados às espécies. A análise de RAPD provou ser um método eficiente para detecção da variabilidade genética entre isolados de A. alternata e $A$. cassiae ocorrendo em $S$. obtusifolia, e também para distinguir as espécies de Alternaria.

Palavras-chave: Fungos, Senna obtusifolia, bioherbicida, controle microbiano

\section{REFERENCES}

1. Aljanabi S.M.; Martinez, I. Universal and rapid salt-extraction of high genomic DNA for PCR-based techniques. Nucleic Acid Res., 25: 4692-4693, 1997.

2. Charudattan, R. Biological control of weeds: an international overview. V Simpósio de Controle Biológico, Foz do Iguaçu, 1996, p. 270-282.

3. Inglis, P.W.; Teixeira, E.A.; Ribeiro, D.M.; Valadares-Inglis, M.C.; Tigano, M.S.; Mello, S.C.M. Molecular markers for the characterization of Brazilian Cercospora caricis isolates. Curr. Microbiology, 42: 194-198, 2001.

4. Mello, S.C.M.; Ribeiro, Z.M.A.; Sousa, G.R.; Tigano, M.S.; Nachtigal, G.F.; Fontes, E.M.G. Padrões isoenzimáticos e morfologia de isolados de Alternaria spp. patogênicos a Senna obtusifolia. Fitopat. Bras., 26: 667-669, 2001

5. Rohlf, F.J. NTSYS-pc v. 1.8. Numerical taxonomy and multivariate analysis system. Applied Biostatistics Inc. Setauket, NY, 1993, 191p.

6. Sambrook, J.; Fritsch, E.F.; Maniatis, T. Molecular Cloning: A Laboratory Manual, $2^{\text {nd }}$ ed. Cold Spring Harbor Laboratory Press, NY, 1989, 120p.

7. Simmons, E.G. Alternaria themes and variations (7-10). Mycotaxon, 14: 17-43, 1982.

8. Sneath, P.H.A.; Sokal, R.R. Numerical Taxonomy. Freeman, San Francisco, 1973, 573 p.

9. Tigano-Milani, M.S.; Honeycutt, R.J.; Lacey, L.A.; Assis, R.; McClelland, M.; Sobral, B.W.S. Genetic variability of Paecilomyces fumosoroseus isolates revealed by molecular markers. J. Invertebr. Pathol., 65: 274-282, 1995a.

10. Tigano-Milani, M.S.; Samson, R.R.; Martins, I.; Sobral, B.W.S. DNA markers for differentiating isolates of Paecilomyces lilacinus. $J$. Gen. Microbiol., 141: 239-245, 1995 b. 